\title{
Medication Error due to Application Program Problem
}

National Cancer Institute

\section{Source}

National Cancer Institute. Medication Error due to Application Program Problem. NCI

Thesaurus. Code C91396.

An error in medication preparation or administration attributed to software. 